\title{
MALLEABILITY AND METALLOGRAPHY OF NICKEL
}

\author{
By P. D. Merica and R. G. Waltenberg
}

\begin{abstract}
In the manufacture of "malleable" products of nickel and certain nickel alloys, such as forgings, rolled shapes, and castings, rather unusual metallurgical treatments of the molten metal are resorted to in order that the cast product may be sufficiently malleable and ductile for the subsequent forging operations. The principal feature of these treatments is the addition to the molten metal before casting of manganese and magnesium. Ordinary furnace nickel without these additions will give a casting, in general, which is not malleable either hot or cold.

It is demonstrated that such " untreated" nickel, or nickel alloys, are brittle because of the presence of small amounts of sulphur-as little as 0.005 per cent. This sulphur is combined with the nickel as $\mathrm{Ni}_{3} \mathrm{~S}_{2}$, which collects in the form of thin and brittle films around the grains of nickel. This sulphide also melts (as an eutectic with nickel) at a very low temperature, about $630^{\circ} \mathrm{C}$. Hence, at all temperatures the cohesion between the nickel grains is either completely destroyed or at least impaired by the presence of these films of sulphide, and the metal is brittle.

Both manganese and magnesium react with molten $\mathrm{Ni}_{3} \mathrm{~S}_{2}$ to form sulphides of manganese or of magnesium. The latter, in particular, has a very high melting point and, in addition, assumes a form of distribution in the metal mass which affects the malleability but slightly, viz, that of small equiaxed particles uniformly distributed throughout the metal grains. The effect of magnesium addition, therefore, in conferring malleability upon nickel containing sulphur, is due principally to the resulting conversion of $\mathrm{Ni}_{3} \mathrm{~S}_{2}$ into $\mathrm{MgS}$.

This investigation was completed under an industrial fellowship at the Bureau of Standards maintained by the International Nickel Co.
\end{abstract}

\section{CONTENTS}

I. Introduction

II. Method of investigation

1. Preparation of melts_-__-__-_- 158

2. Tests for malleability

III. Results

1. Malleability of pure electrolytic nickel

2. Nickel oxide and nickel

3. Gases in nickel _- 163

4. Sulphur in nickel

5. Other elements

6. Effect of manganese and magnesium 171

7. Effect of excess of magnesium

IV. Summary and conclusions________- 179 


\section{INTRODUCTION}

For many years after the discovery and isolation of nickel in 1750 by Cronstedt this metal was available only in nonmalleable forms-rondelles, cubes, grains, etc. Indeed, this was true even for years after the beginning of its commercial use, such as for plating, alloying, etc. The valuable properties of the pure metal were recognized, but for some time no one was apparently able to cast it in such a manner as to render it amenable to the usual rolling or drawing processes.

In 1878 the firm of Joseph Wharton, of Philadelphia (which later became the American Nickel Works, a constituent company of the International Nickel Co.), exhibited at the Paris Exhibition specimens of rolled pure nickel strip and of drawn nickel wire. Shortiy after this a number of processes were discovered and patented for the production of malleable nickel. Thus, G. A. Boeddicker ${ }^{1}$ describes the use of from $1 \frac{1}{2}$ to 3 per cent of manganese as an addition agent to molten nickel, which renders it malleable. G. Selve and F. Lotter ${ }^{2}$ also describe the use of manganese, and the Bernsdorfer Metallwarenfabrik ${ }^{3}$ claim the use of potassium permanganate solution to be mixed with nickel oxide and allowed to dry, followed by reduction and melting with charcoal in the usual manner. J. Gernier ${ }^{4}$ mentions the use of manganese for the purpose of rendering cast nickel malleable, but prefers the use of phosphorus (up to 0.003 per cent) added as a phosphor-nickel alloy.

It is evident that the remedies so proposed were based upon the thought that the brittleness of the usual cast nickel was due to the presence of nickel oxide, and, indeed, this thought was usually explicitly stated in the discussion and claims of these experimenters.

The most practical method of producing malleable nickel had already been discovered and described in 1879 by Th. Fleitmann. ${ }^{5}$ Fleitmann discovered and patented the addition to the molten nickel before casting of metallic magnesium in amounts of from 0.05 to 0.125 per cent, and later amended this practice to use a magnesiumnickel alloy instead. This operation worked excellently and became shortly thereafter the recognized method for treating nickel in order to render it ductile.

Fleitmann did not speak of this operation as designed to remove nickel oxide, but believed that it removed either carbon monoxide (by reduction to carbon) or cyanogen compounds. He called at-

1 The Wiggin process for production of malleable nickel; Wagner's Jahresberichte 27, p. $69 ; 1881$.

${ }^{2}$ Production of nickel free from oxide; German patent $25798 ; 1883$.

3 German patent 28989; 1884 .

4 Un a new process of obtaining malleable nickel; C. R. 91, p. $331 ; 1880$.

5 Ber. d. deutsch Gesell., 12, p. 454; 1879. 
tention to the fact that this use of magnesium secures the production of castings which are both malleable and sound; that is, free from gas inclusions. He refers also later ${ }^{6}$ to the use of manganese to flux and remore sulphur, a most interesting suggestion, anticipating in a general way the conclusions reached in this investigation.

After the lapse of about 45 years we find the Fleitmann method, a bit modified it is true, still used exclusively for the treatment of nickel intended for malleable castings, as well as for the treatment of many nickel-bearing alloys, such as Monel metal and other copper-nickel alloys. Even with modern methods of refining and improred furnace practice, nickel-alloy castings are not, in general, malleable without the magnesium treatment. It is customary to-day to use for this purpose about 0.1 per cent of metallic magnesium, usually in conjunction with 0.25 per cent or more of manganese in one of its usual commercial forms.

The Fleitmann method has, in fact, been so brilliantly successful that since the day of its discovery no one has apparently found it necessary to give any consideration to the mechanism by which the effect is produced. It has worked and does work, why bother about how it works. The producers of nickel alloys have thankfully availed themselves of its beneficial effect and, for convenience, referred to its effect as one of deoxidation and degasification, apparently the accepted explanation.

In recent years, however, a number of both major and minor phenomena have served to focus our attention again upon this question, and it has become increasingly evident that there was something else in the action of magnesium on nickel and its alloys than deoxidation or degasification.

The investigation here reported was taken up in the summer of 1921 with the specific purpose of ascertaining (1) why ordinary cast nickel is not malleable, when not treated with magnesium, and (2) what is the mechanism by which the magnesium treatment produces malleability in such nickel. It is obvious that such an investigation has of necessity embraced as well a considerable study of the metallography of nickel and some of its alloys and has brought to light some other interesting facts only indirectly related to the principal themes. Of these, perhaps, the most interesting are the results of the study made of the equilibrium between nickel and nickel oxide.

The metallography of nickel and its alloys has been the subject of a number of most valuable investigations, of which it is unnecessary to mention all in this place. A discussion and bibliography of these investigations is given in Bureau of Standards Circular No. 100 on Nickel, and we should like to refer also to the very practical

\footnotetext{
${ }^{\circ}$ German patent 28460; 1884.
} 
remarks on this subject by D. H. Browne and J. F. Thompson. ${ }^{7}$ which cover particularly the metallography of nickel with small amounts of the usual commercial impurities.

\section{METHOD OF INVESTIGATION}

Inasmuch as the first problem of this investigation was to determine why and under what conditions cast nickel is not malleable, recourse was had at once to the preparation, on a small laboratory scale, of test melts and cast ingots of nickel prepared under a variety of conditions and with various metallic and nonmetallic additions. The ingots of these melts were tested both hot and cold for malleability, and many were examined also by thermal and metallographic methods.

\section{PREPARATION OF MELTS}

Three furnaces were used in the preparation of these melts in order to embrace a variety of melting conditions-a gas-fired crucible furnace, a high-frequency induction furnace, and the Arsem furnace.

The melts in the induction furnace were made in specially prepared magnesia crucibles or in crucibles of "impervite," a commercial refractory porcelain. These crucibles were cylindrical and were of two sizes,. $22 \mathrm{~mm}$ (0.86 inch) in diameter and $75 \mathrm{~mm}$ (3 inches) high, or $35 \mathrm{~mm}$ (1.4 inches) in diameter and $75 \mathrm{~mm}$ (3 inches) high. No ingots could be poured from these crucibles. It was necessary to melt a charge, make the desired additions, and allow the melt to solidify in the crucible. Some melts were made in this furnace by using larger crucibles, additions were made and ingots poured after each addition. Additions of magnesium were not satisfactory, as the magnesium would cause violent spitting, caused possibly by the relatively small cross section of the crucible. The melts in this furnace were made by direct induction, the current producing the heat being developed in the charge.

A few melts were made in an Arsem furnace to study the effect of melting under vacuo, hydrogen, and carbon monoxide. These melts were made in magnesia or "impervite" crucibles $18 \mathrm{~mm}(0.7$ inch) in diameter and $75 \mathrm{~mm}$ (3 inches) high. The crucible containing the material to be melted was placed in a protecting tube which was then inserted in the furnace. The furnace was closed, evacuated, and the charge could then be melted. Hydrogen or carbon monoxide could be introduced or pumped from the furnace at any stage of the run. As it was necessary to allow the furnace to cool before opening, no additions were made to melts made in this furnace.

${ }^{7}$ The physical properties of nickel ; Trans., A. I. M. E., 64, p. $387 ; 1920$. 
The melts in the gas furnace were made in covered No. 10 plumbago crucibles, the procedure being as follows: The charge, usually consisting of $3,000 \mathrm{~g}$ (6.8 pounds) of electrolytic nickel with a little charcoal, would be placed in a crucible previously heated to a high temperature. It required about one and one-quarter hours to heat the melt to a proper pouring temperature. An ingot weighing about $5 \check{5} 0 \mathrm{~g}$ (1.2 pounds) would be poured, an addition to produce a desired alloy would be made and a second ingot poured. Further additions would be made and other ingots poured until the desired ingots were obtained or until the melt became too cold to pour properly. This usually occurred after pouring the third ingot. The melt would then be replaced in the furnace, reheated for about 15 minutes, and the procedure of making additions and pouring continued. In no case was a melt reheated after an addition of magnesium. From three to six ingots were produced from each melt.

These ingots were cast in tapering split-steel molds with a circular cross section. The diameter of the ingots was $20 \mathrm{~mm}(0.8$ inch $)$ at the bottom, $30 \mathrm{~mm}$ (1.2 inches) at the top, with a sink head which tapered from 30 to $50 \mathrm{~mm}$ ( 2 inches) in $9 \mathrm{~mm}(0.35$ inch). The length of the ingots, exclusive of the sink head, was $110 \mathrm{~mm}(4.3$ inches). The weight of the ingots with sink head was about $550 \mathrm{~g}$ (1.2 pounds).

The sulphur content of our alloys was controlled by adding weighed amounts of nickel-sulphur alloys of known composition. These nickel-sulphur alloys were made by adding nickel sulphide $\left(\mathrm{Ni}_{3} \mathrm{~S}_{2}\right)$ to molten nickel and contained about 2 per cent sulphur.

Granular metallic manganese and metallic magnesium were used for the additions of these elements. During the first part of this work the pieces of magnesium were held in nickel tongs and plunged into the molten charge, later the additions were made by wedging the magnesium in the end of a carbon rod which was then plunged into the molten charge.

The methods we used for introducing other elements, such as silicon and arsenic, are described in the section of this report dealing with the tests made on alloys containing these elements.

\section{TESTS FOR MALLEABILITY}

The malleability of the alloys was determined at 1,000 to $1,100^{\circ} \mathrm{C}$. $\left(1,830\right.$ to $2,010^{\circ} \mathrm{F}$.) by hammering one end of a specimen to a wedge. If no cracks were visible at the edge and sides of the wedge, the specimen was termed malleable. No attempt was made to grade the alloys into more than the two classes, malleable and nonmalleable.

The lower end of an ingot, rounded by filing, was usually taken for this test. A specimen to be forged was placed on the apron of a gas forge for about 10 minutes, then in the forge, which was held 
at $1,100^{\circ}$ C. $\left(2,010^{\circ} \mathrm{F}\right.$. $)$, for about 10 minutes. It was then hammered on an anvil with a 5-pound hammer. The alloys containing above 0.2 per cent carbon or manganese usually required more than one heating in order to forge to a satisfactory wedge while hot.

It is believed that this test for malleability as we applied it was not a particularly severe one as compared with commercial forging and rolling operations. Some specimens, such as $\mathrm{N}-1$, containing 0.01 per cent sulphur which could be forged to a wedge nicely but

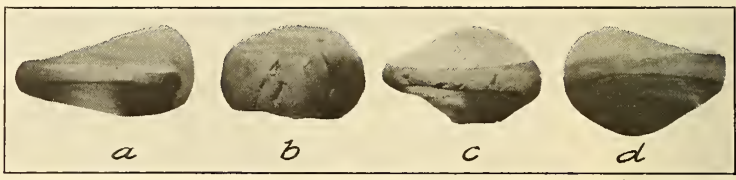

Fig. 1.- Appearance of a set of forged nickel specimens illustrating the effeet of additions upon malleability, $\times 1$

(a) Specimen 74, nickel containing 0.005 per cent sulphur

(b) Specimen 741 , nickel containing 0.021 per cent sulphur

(c) Specimen $7+B$, same as $74 \mathrm{~A}$ after addition of 0.24 per cent manganese

(d) Specimen $74 C$, same as $74 \mathrm{~B}$ after addition of 0.1 per cent magnesium

could not be drawn into a bar would crack after repeated heatings followered by hammering.

The appearance of a set of forged specimens from one melt is shown in Figure 1.

\section{RESULTS}

\section{MALLEABILITY OF PURE ELECTROLYTIC NICKEL}

It was determined that commercial electrolytic nickel was malleable before and after remelting. The nickel used was obtained from two sources, the Orford and the Port Colborne works of the International Nickel Co. The composition of two shipments of these nickels, as determined by J. A. Scherrer, chemist of the Bureau of Standards, was as follows:

\begin{tabular}{|c|c|c|c|c|c|c|}
\hline & $\mathrm{Cu}$ & Co & $\mathrm{Fe}$ & C & $\mathrm{S}$ & $\begin{array}{l}\mathrm{Ni} \text { (by } \\
\text { differ- } \\
\text { ence) }\end{array}$ \\
\hline $\begin{array}{l}\text { Orford works } \\
\text { Port Colborne works. }\end{array}$ & $\begin{array}{r}\text { Percent } \\
0.12 \\
.01\end{array}$ & $\begin{array}{r}\text { Percent } \\
0.36 \\
.24\end{array}$ & $\begin{array}{r}\text { Pet cent } \\
0.11 \\
.11\end{array}$ & $\begin{array}{c}\text { Percent } \\
0.005 \\
0.03\end{array}$ & $\begin{array}{r}\text { Per cent } \\
0.002 \\
.001\end{array}$ & $\begin{array}{r}\text { Per cent } \\
99.4 \\
99.6\end{array}$ \\
\hline
\end{tabular}

Note.-Si, Mn, Pb, Mg, As, Sb, and Sn were not detected in either.

A piece of each of these cathode nickels was cold-rolled to about 0.12 inch, then cold-drawn to 0.022 inch, No. 23 B. \& S. gauge. No difficulty was experienced in drawing this wire without any heat treatment. 
Malleable ingots of composition shown in Table 1 were produced by melting these nickels in racuo, in an open crucible in an induction furnace; and in a gas-fired furnace. No difference was observed in the forging properties of these nickels, and both were used in the preparation of alloys for this investigation.

\section{NICKEL OXIDE AND NICKEL}

It has generally been considered that the presence in cast nickel of nickel oxide renders it nonmalleable. I number of melts was, therefore, made to investigate this point.

Nickel melted in the presence of oxygen forms an oxide ( $\mathrm{NiO}$ ) which forms an eutectic with nickel. This eutectic contains about 0.24 per cent oxygen, corresponding to 1.1 per cent $\mathrm{NiO}$, and melts at $1,438^{\circ} \mathrm{C} .\left(2,620^{\circ} \mathrm{F}\right.$. $), 14^{\circ}$ below the melting point of nickel. The oxygen content of the eutectic was determined by L. Jordan, chemist of this bureau, by using the racuum fusion method of analysis, and was checked by the solution method for oxide determinations used by the International Nickel Co. The composition of the oxide was determined as $\mathrm{NiO}$ by analyses of the oxide residue obtained in the latter method of analysis. The microstructures of several specimens containing the oxide eutectic, and one containing free primary oxide, are shown in Figure 2.

The eutectic temperature was determined directly by thermal analysis of specimens placed in vacuo directly upon the hot junction of a platinum, platinum rhodium thermo-couple. The melting point of nickel oxide was determined by C. O. Fairchild, physicist of this bureau, with a micropyrometer. Black nickel oxide from the International Nickel Co. melted at $1,652^{\circ}$ C. and Kahlbaum nickel oxide at $1,660^{\circ} \mathrm{C}$. Microscopic examination indicated the presence of only one oxide in nickel. The oxide content in melts made both in vacuo and under one atmosphere pressure of air, and carrying from 0.05 to 6.5 per cent oxygen, was shown by direct analysis to be $\mathrm{NiO}$. It seems, therefore, that the evidence here presented is sufficiently complete to establish the fact that $\mathrm{NiO}$ forms a simple eutectic series with nickel, stable at least up to 25 per cent nickel oxide, and probably up to the melting point of nickel oxide itself. The iiquidus temperatures within this series were not directly determined.

Contrary to expectation, we found that nickel containing nickel oxide, at least up to the eutectic composition, is malleable. A number of ingots containing oxygen in varying amounts up to the eutectic composition were tested, and all were malleable. Further to demonstrate this point, a wire 0.009 inch in diameter, No. 31 B. \& S. gauge, was drawn from a specimen (No. 60) consisting of the eutectic of nickel and nickel oxide, of which the microstructure is $24304^{\circ}-25-2$ 


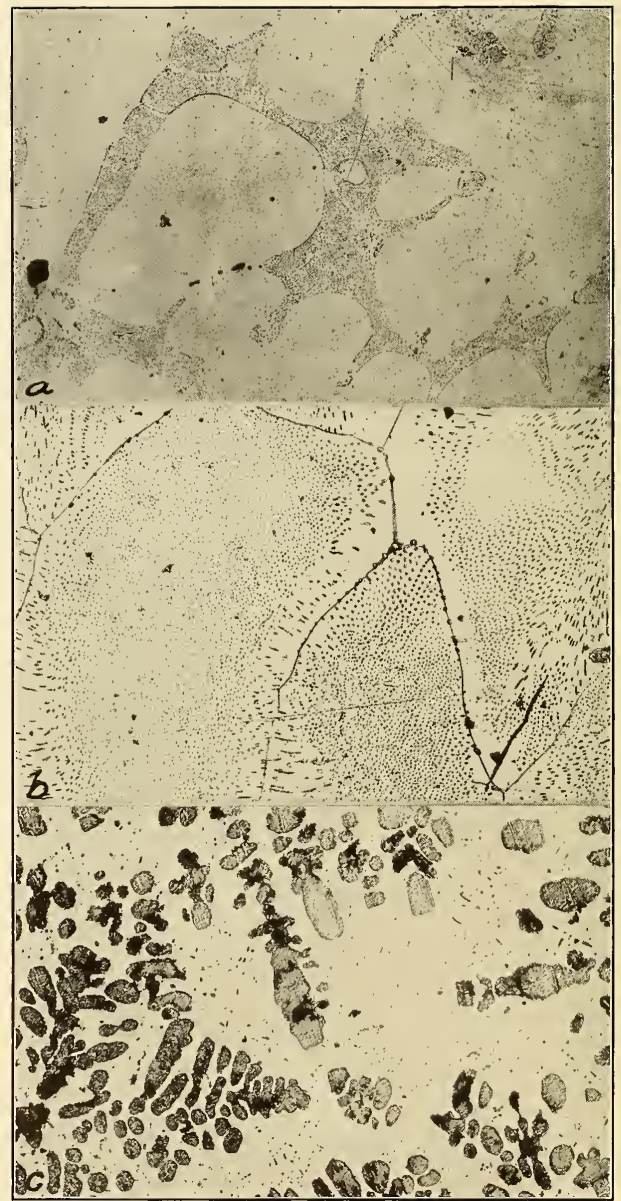

Fig. 2.-Microstructure of nickel containing various amounts of oxygen, $\times 100$

(a) Specimen 1, etched, containing approximately 0.20 per cent of the nickel-nickel oxide eutectic

(b) Specimen 60, etched, eutectic composition, 0.24 per cent oxygen (1.1 per cent nickel oxide)

(c) Specimen 59, unetched, contains 11 per cent of the free or primary nickel oxide.

A water solution of nitric and acetic acid (30 parts by volume concentrated nitric acid, 30 glacial acetic acid, 40 water) was used for the etching here and elsewhere 
shown in Figure 2b. To produce this wire, the ingot was forged at 1,050 to $1,100^{\circ} \mathrm{C}$. to a round bar about 0.25 inch in diameter. It was then drawn cold through dies which were in steps of 5 to 10 per cent reduction of area. At 0.097 inch in diameter it was annealed by heating to a bright red over an open gas flame, and the drawing continued with similar annealing at about every 80 per cent of area.

A eutectic of the oxide in Monel metal has not been identified. The oxide apparently separates to the grain boundaries of the Monel metal as free oxide. It has the appearance of nickel oxide, and analyses of different specimens gave various proportions of nickel, copper, and iron oxides. This oxide in small amounts also has no appreciable effect on the malleability of Monel metal.

\section{GASES IN NICKEL}

It was considered that the nonmalleability of nickel might be due to the presence of gases, and several melts were, therefore, made in such a manner as to introduce the maximum amount of certain gases into the molten metal. Trials were made with electrolytic nickel (1) by melting and solidifying under hydrogen, (2) by melting and solidifying under carbon monoxide, (3) by melting in a gas-fired furnace in an open crucible, and (4) by melting in an induction furnace in an open crucible. All of the ingots so produced were malleable. Likewise, a malleable ingot was produced when nickel oxide was reduced, melted, and solidified under carbon monoxide. A melt of nickel containing oxide was reduced by the addition of carbon and a malleable ingot produced.

One is forced to conclude from these tests that nickel is not rendered nonmalleable by the presence of $\mathrm{CO}, \mathrm{CO}_{2}, \mathrm{O}_{2}$, or $\mathrm{N}_{2}$. Cyanogen was not tried, although the open crucible experiments allowed opportunity for its formation if it were stable under these conditions.

\section{SULPHUR IN NICKEL}

It will be noted that the experiments up to this stage had yielded the rather unexpected result that none of the conditions or additions produced nonmalleability. The addition of even small amounts of sulphur, however, rendered nickel nonmalleable, both hot and cold. A number of melts were made under various conditions to demonstrate this satisfactorily. The results are shown in Tables 1 and 2, where the composition of a number of malleable and nonmalleable specimens of nickel and Monel metal are listed. 
TABLE 1.-Malleable specimens (not treated with magnesium)

NICKEL

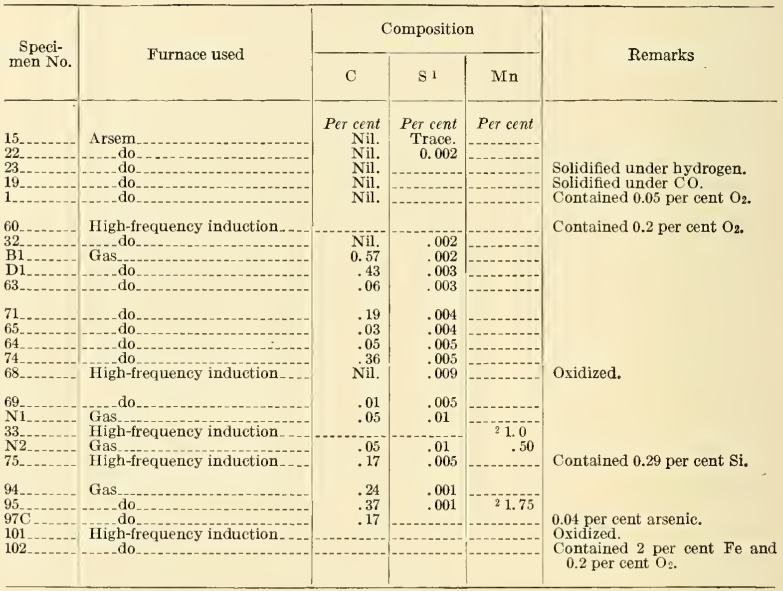

MONEL METAL

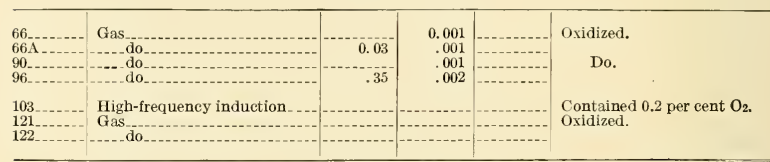

1 Some of these sulphur analyses were made by the evolution and some by the gravimetric method and are regarded as accurate within \pm 0.003 per cent.

2 A mount added to melt.

TABLE 2.-Nommalleable specimens (not treated with magnesium)

NICKEL

\begin{tabular}{|c|c|c|c|c|c|}
\hline \multirow{2}{*}{$\begin{array}{c}\text { Speci- } \\
\text { men No. }\end{array}$} & \multirow{2}{*}{ Furnace used } & \multicolumn{3}{|c|}{ Composition } & \multirow{2}{*}{ Remarks } \\
\hline & & $\mathrm{C}$ & S 1 & Mn & \\
\hline $\begin{array}{l}27 \\
67 \\
69 \mathrm{~A} \\
67 \mathrm{~A} \\
67\end{array}$ & $\begin{array}{l}\text { Arsem } \\
\text { High-frequeney induction }\end{array}$ & $\begin{array}{r}\text { Per cent } \\
\text { Nill. } \\
0.01 \\
.01 \\
.02 \\
.01\end{array}$ & $\begin{array}{c}\text { Per cent } \\
0.008 \\
.01 \\
.01 \\
.017 \\
.017\end{array}$ & Per cent & \\
\hline $\begin{array}{l}64 \mathrm{~A} \\
63 \mathrm{~A} \\
74 \mathrm{~A} \\
74 \mathrm{~B} \\
65 \mathrm{~B} \\
\end{array}$ & $\begin{array}{l}\text { Gas } \\
\text { do do }\end{array}$ & $\begin{array}{l}.05 \\
.04 \\
.32 \\
.30 \\
.03\end{array}$ & $\begin{array}{l}.020 \\
.020 \\
.021 \\
.021 \\
.021\end{array}$ & $\begin{array}{r}0.24 \\
.11\end{array}$ & \\
\hline
\end{tabular}

1 Some of these sulphur analyses were made by the evolution and some by the gravimetric method and are regarded as accurate within \pm 0.003 per cent. 
TABLE 2.-Tonmalleable specimens (not treated with magnesium)-Continued

NICKEL-Continued

\begin{tabular}{|c|c|c|c|c|c|}
\hline \multirow{2}{*}{$\begin{array}{l}\text { Speci- } \\
\text { men No. }\end{array}$} & \multirow{2}{*}{ Furnace used } & \multicolumn{3}{|c|}{ Composition } & \multirow{2}{*}{ Remarks } \\
\hline & & $\mathrm{C}$ & $\mathrm{S}$ & $\mathrm{Mn}$ & \\
\hline $\begin{array}{l}62 \mathrm{~A} \\
62 \mathrm{~B} \\
69 \mathrm{~B} \\
71 \mathrm{~A} \\
71 \mathrm{~B} \\
71 \mathrm{n}\end{array}$ & $\begin{array}{l}\text { Gas } \\
\text { Gigh-frequency induction. } \\
\text { Gas do }\end{array}$ & $\begin{array}{r}\text { Per cent } \\
0.02 \\
.02 \\
.01 \\
.02 \\
.03\end{array}$ & $\begin{array}{r}\text { Per cent } \\
0.024 \\
.023 \\
.023 \\
.023 \\
.023\end{array}$ & Per cent & \\
\hline $\begin{array}{l}\mathrm{K} 3 \\
64 \mathrm{~B} \\
65 \mathrm{~A} \\
63 \mathrm{~B} \\
\mathrm{D} 2\end{array}$ & \begin{tabular}{|c|c|} 
\\
\end{tabular} & $\begin{array}{l}.07 \\
.05 \\
.02 \\
.01 \\
.44\end{array}$ & $\begin{array}{l}.024 \\
.025 \\
.026 \\
.027 \\
.034\end{array}$ & $\begin{array}{r}.37 \\
.20 \\
.18 \\
-1 .-\end{array}$ & \\
\hline $\begin{array}{l}68 \mathrm{~A} \\
68 \mathrm{~B} \\
84 \mathrm{~A} \\
95 \mathrm{~A}\end{array}$ & $\begin{array}{l}\text { High-frequency induction. . } \\
\text { Gas do }\end{array}$ & $\begin{array}{l}\text { Nil. } \\
\text { Nil. } \\
.52 \\
.34\end{array}$ & $\begin{array}{l}.013 \\
.014 \\
.028 \\
.045\end{array}$ & 11.75 & $\begin{array}{c}\text { Oxidized. } \\
\text { Do. }\end{array}$ \\
\hline
\end{tabular}

MONEL METAL

\begin{tabular}{|c|c|c|c|c|c|}
\hline $\begin{array}{l}66 \mathrm{~B} \\
66 \mathrm{C}-\ldots . . \\
90 \mathrm{~A}-\ldots . \\
96 \mathrm{~A} \\
96 \mathrm{~B} \\
96 \mathrm{C} \\
9 \ldots\end{array}$ & 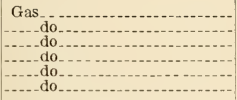 & $\begin{array}{r}0.02 \\
.01 \\
.35 \\
.35 \\
.35\end{array}$ & $\begin{array}{r}0.009 \\
.009 \\
.015 \\
.004 \\
.008 \\
.010\end{array}$ & 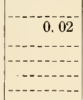 & $\begin{array}{l}\text { Oxidized. } \\
\text { Very fine eracks. }\end{array}$ \\
\hline
\end{tabular}

1 Amount added to melt.

NotE.-Malleable ingots were obtained from melts $\mathrm{K}, 63,66,71,74$, and 84 by the addition of 0.1 per cent $\mathrm{Mg}$.

To demonstrate that Monel metal low in sulphur is malleable, a wire 0.009 inch in diameter, No. 31 B. \& S. gauge, was drawn from an ingot (No. 96) containing 0.37 per cent carbon and 0.002 per cent sulphur. This ingot was cast from a gas furnace melt composed of 69.4 per cent electrolytic nickel, 28.6 per cent electrolytic copper, 2 per cent electrolytic iron, and a little charcoal. This ingot was poured before any additions were made to the melt. The ingot was forged at 1,000 to $1,100^{\circ} \mathrm{C}$. to a bar about 0.5 inch in diameter. It was then drawn cold with annealings at $950^{\circ} \mathrm{C}$. at about every 80 per cent reduction of area to 0.033 inch in diameter, and then it was drawn cold to 0.009 inch in diameter.

The reason for this very striking effect of sulphur in nickel is not far to seek. Bornemann. ${ }^{8}$ Hayward,${ }^{9}$ and others have studied the equilibrium of nickel and sulphur and have shown that sulphur forms a compound $\left(\mathrm{Ni}_{3} \mathrm{~S}_{2}\right)$ which forms a eutectic with nickel at 21.5 per cent sulphur that melts at $644^{\circ} \mathrm{C}$. This compound when present in small amounts in cast nickel assumes the form of films surrounding partially or completely the individual grains of nickel.

${ }^{8}$ Metallurgie, 5, p. $13: 1908 ; 7$, p. $667 ; 1910$.

o Trans. A. I. M. E., 48 , p. $141 ; 1914$. 


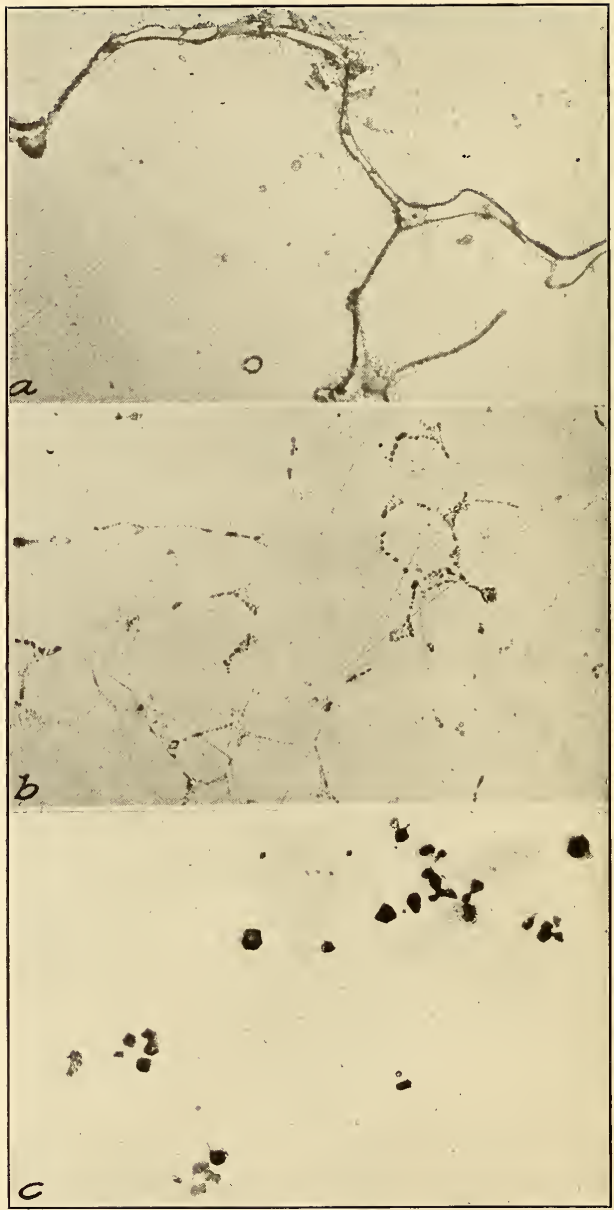

Fig. 3.-Physical state in which sulphur may occur in nickel, $\times 500$

(a) Specimen $83 \mathrm{~A}$, etched, nickel containing 0.23 per cent sulphur. The nickel sulphide shows as conspicuous films at the grain boundaries

(b) Specimen $83 \mathrm{~B}$, etched, same as $83 \mathrm{~A}$ treated with 3 per cent manganese. The manganese sulphide appears as a cutectic network at the grain boundaries

(c) Specimen $83 \mathrm{C}$, unetched, same as $83 \mathrm{~B}$, treated with 0.5 per cent magnesium. The magnesium sulphide appears as hexagonal inclusions within the nickel grains 
It has a characteristic yellowish color and is readily identified under the microscope. It is shown in Figures 3, 4, and 5. It appears from the malleability tests that the solubility of this compound in nickel (solid solution) must be extremely slight, corresponding to less than 0.005 per cent sulphur. The presence of this compound in nickel in amounts corresponding to as little as 0.02 per cent sulphur (untreated) can be detected both by thermal analysis and microscopically after annealing. The malleability tests are still more sensitive to its presence, howerer, and indicate the lower limit of solubility indicated. Its effect in rendering nickel nonmalleable is readily understood.

The sulphur constituent in Monel metal does not have the same color as in nickel, and collects in globules at the grain boundaries rather than as a network. This constituent has a dark blue color and is attacked by five seconds' immersion in a 10 per cent aqueous solution of KCN. The oxide in nickel and Monel and the nickel sulphide in nickel are not attacked under similar conditions. This constituent apparently is $\mathrm{Cu}_{2} \mathrm{~S}$, and as it is visible in Monel metal containing 0.01 per cent sulphur as cast, and after annealing at $700^{\circ} \mathrm{C}$. its solubility must be very low. The structure of Monel metal containing sulphur, and before manganese or magnesium treatment, is shown in M1 (fig. 6). The web-like structure of the grains in M1 is associated in commercial practice with nonmalleable Monel metal and is possibly due to a sulphide eutectic. It has not appeared in any of the small experimental specimens which were treated with manganese or magnesium. Thermal analyses indicate that this sulphide eutectic melts at $570^{\circ} \mathrm{C} .\left(1,058^{\circ} \mathrm{F}\right.$.).

\section{OTHER ELEMENTS}

It appeared hardly necessary to give consideration to the possible effect of certain impurities, such as iron, cobalt, copper, and manganese, since these are known to form solid solutions with nickel within wide limits. Likewise, carbon, silicon, and arsenic could hardly be suspected, but actual trials were made, electrolytic nickel with additions of these elements being used.

Silicon in amounts usually present in commercial nickel does not make it nonmalleable. A nickel containing 0.17 per cent carbon, 0.005 per cent sulphur, and 0.29 per cent silicon was prepared in an induction furnace and found to be malleable. The silicon was introduced by adding metallic silicon to the molten nickel. The amount added was 0.35 per cent.

Several ingots containing 0.17 per cent carbon and arsenic in amounts up to 0.04 per cent were cast from a melt in a gas furnace. All of these ingots were malleable, so arsenic in anounts occurring 


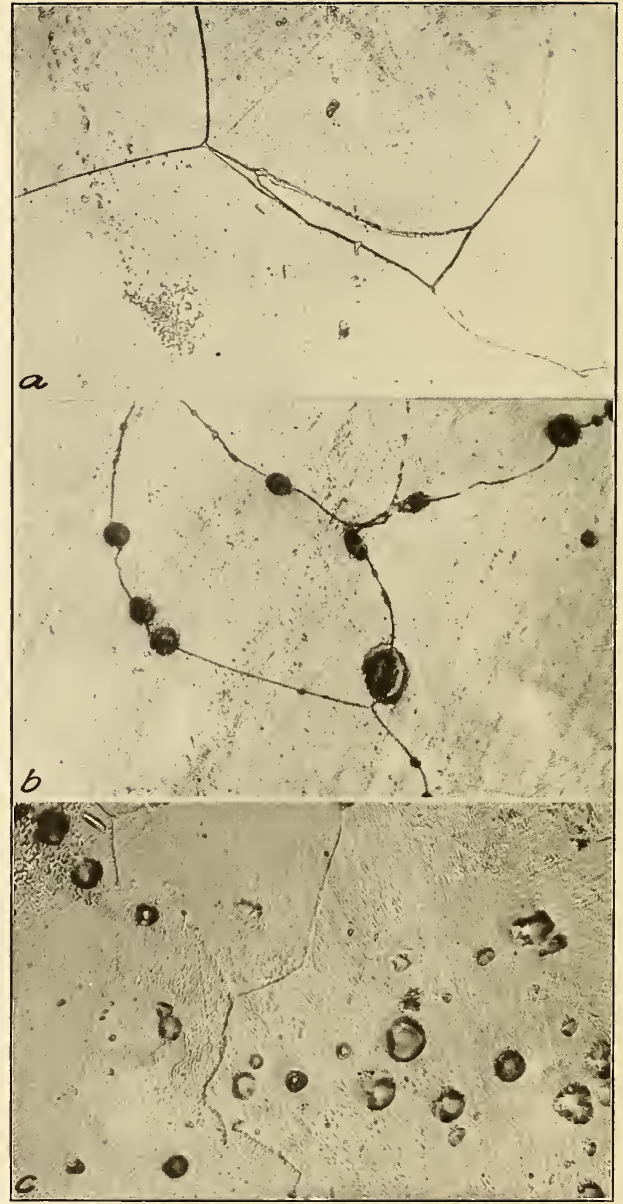

Fig. 4.-Effect of treatment uth manganese and with magnesium upon the condition in whieh sulphur occurs in nickel, $\times 500$

(a) Specimen $74 \mathrm{~A}$, etched, nickel containing 0.21 per cent sulphur. Note the intercrystalline sulphide film

(b) Specimen $74 \mathrm{~B}$, etched, same as $74 \mathrm{~A}$ after treatment with 0.24 per cent manganese. Note the manganese sulphite globules at grain boundaries

(c) Specimen $74 \mathrm{C}$, etched, same as $7 \mathrm{HB}$ after addition of 0.1 per cent magnesium. The pits resulting from the decomposition of the magnesium sulphide by the etching reagent used, indicate the distribution of this constituent 


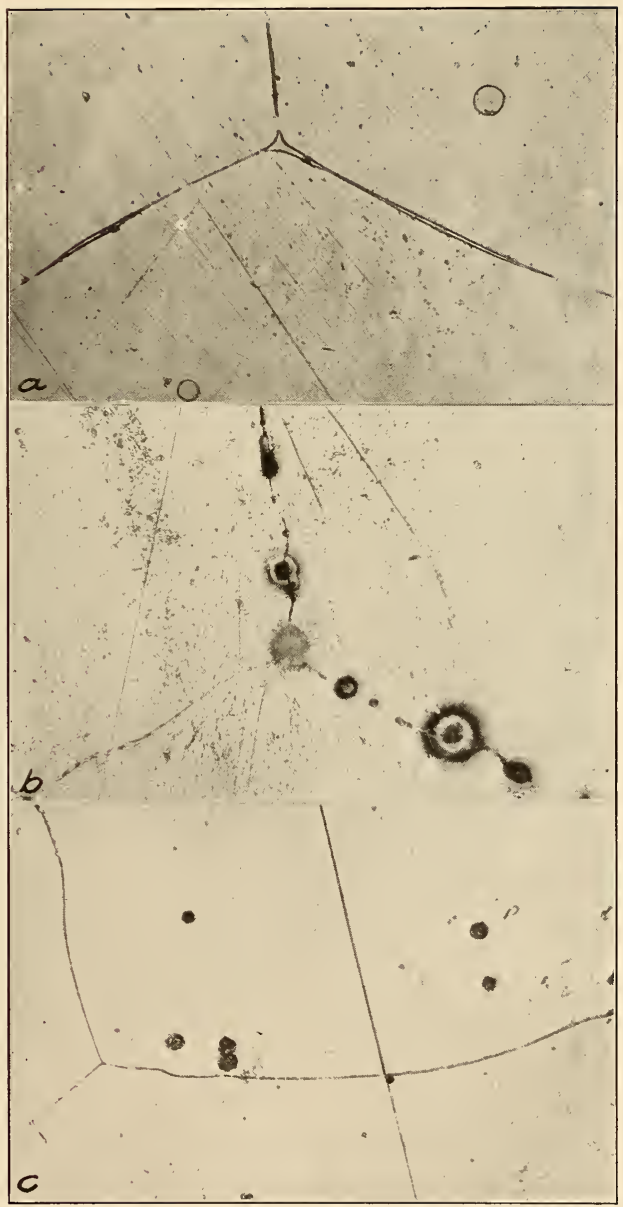

Fig. 5.-Occurrence of sulphur in a commercial melt of nickel as affected by mctallurgical treatment, $\times 500$

(a) Specimen $\mathrm{X} 1$, etched. This was taken during the tapping of the furnace and contains 0.025 per cent sulphur. Note the intercrystalline films also the globules within the grains

(b) Specimen $\mathrm{X} 2$, etched. Same as $\mathrm{X} 1$ after the addition of 0.5 per cent manganese. Note the globules at the grain boundaries

(c) Specimen $\mathrm{X} 3$, etched, same as $\mathrm{X} 2$ after the addition of 0.1 per cent magnesium. Note the globules of magnesium sulphide within the grains 


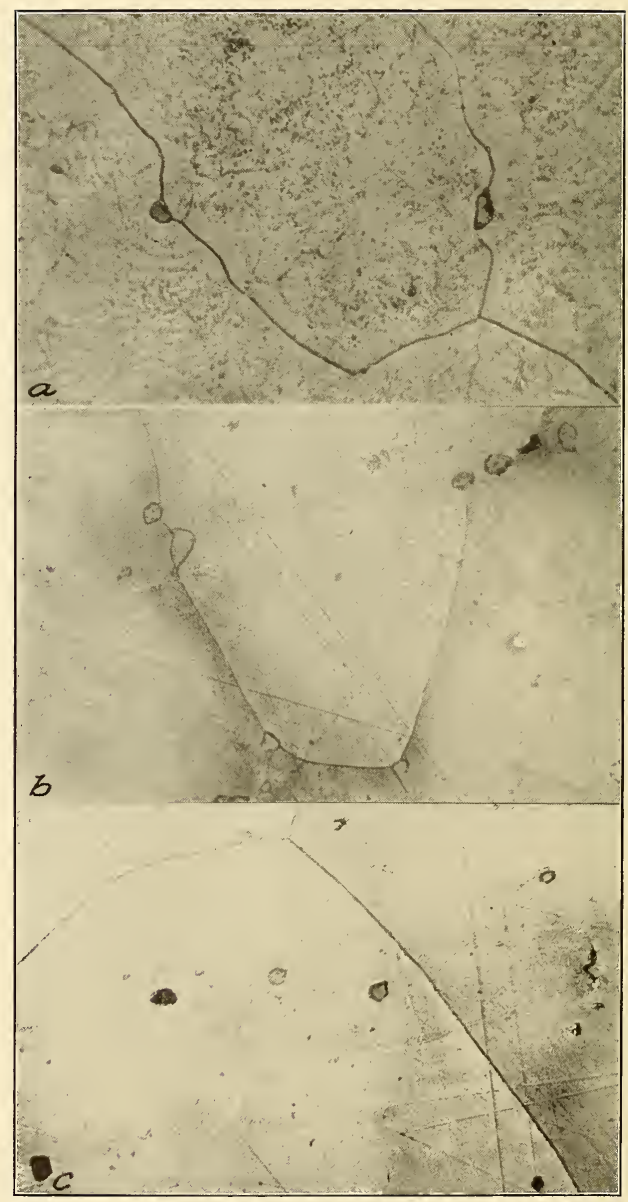

Fig. 6.-Occurrence of sulphur in a commcrcial melt of Honel metal as affected by metallurgical treatment, $\times 500$

(a) Specimen M1, etched. Sample of Monel metal taken during tapping of the furnace, 0.029 per cent nickel. A sulphur constituent appears as globules at the grain boundaries

(b) Specimen M2, etched, same as M1 after addition of 1.65 per cent manganese. The manganese sulphide occurs as globules at the grain boundaries

(c) Specimen $\mathrm{M3}$, etched, same as $\mathrm{M2}$ after addition of 0.1 per cent magnesium. Note the sulphide within the grains 
in commercial nickel does not make it nonmalleable. The arsenic was added to the molten nickel as metallic arsenic inclosed in nickel capsules. The total amount added was 0.045 per cent, and a chemical analysis on the final ingot gave the arsenic content as 0.04 per cent.

Commercial practice of adding carbon and manganese to nickel indicates that these elements in ordinary amounts do not make nickel nonmalleable. To determine their effect on electrolytic nickel several melts were made containing various amounts of carbon and manganese. The ingots from these melts were malleable, and the compositions of some of them, containing carbon or manganese or both, are listed in Table 1.

\section{EFFECT OF MANGANESE AND MAGNESIUM}

Haring thus demonstrated, as we believe, that it is sulphur and sulphur alone of the common impurities which renders ordinary cast nickel nonmalleable without treatment, it remained to study the nature and mechanism of that treatment.

The behavior of these additions to nickel and Monel was demonstrated in the following manner: Several series of melts with varying carbon content ( 0.05 to 0.5 per cent) were obtained in the gas furnace, each melt furnishing several ingots after successive treatments or additions to the melt. The first ingot from a melt of electrolytic nickel invariably would prove to be malleable, then about 0.015 per cent sulphur was added to the melt in the form of a high sulphur alloy containing about 2 per cent sulphur, and the second ingot poured, which on forging proved to be brittle. Then 1 per cent manganese was added to the remaining molten nickel and the third ingot poured, which could be forged a little, but would develop cracks. $\Lambda$ final addition to the "melt" of 0.1 per cent magnesium was made and the last ingot poured, which was always malleable. This same procedure was followed and gave similar results with Monel metal made by melting a charge consisting of 69.4 per cent electrolytic nickel, 28.6 per cent electrolytic copper, and 2 per cent electrolytic iron. The appearance of a set of such specimens of nickel after forging is shown as Figure 1.

Table 3 lists the composition of a number of nonmalleable ingots, and those melts from which malleable ingots were produced after the addition of magnesium are designated.

An addition of manganese is not required for producing malleable metal from nickel or Monel metal containing sulphur. The following table gives the results of tests on specimens containing sulphur, but no manganese, which were made malleable by the additions of magnesium. 
TABLE 3.--Effect of addition of magnesium

\begin{tabular}{|c|c|c|c|c|}
\hline \multirow{2}{*}{ Specimen number } & \multicolumn{3}{|c|}{ Composition } & \multirow{2}{*}{ Behavior on forging } \\
\hline & $\mathrm{C}$ & $\mathrm{S}$ & $\mathrm{Mg}$ & \\
\hline $\begin{array}{l}84 \mathrm{~A} \text {, nickel..... } \\
84 \mathrm{~B} \text {, nickel..... } \\
\text { 84C, nickel.... }\end{array}$ & $\begin{array}{r}\text { Percent } \\
0.52 \\
.52 \\
.52\end{array}$ & $\begin{array}{r}\text { Per cent } \\
0.028 \\
.028 \\
.028\end{array}$ & $\begin{array}{c}\text { Per cent } \\
\text { None. } \\
0.03 \\
.1\end{array}$ & $\begin{array}{l}\text { Brittle. } \\
\text { A few small cracks. } \\
\text { Malleable. }\end{array}$ \\
\hline $\begin{array}{l}111 \mathrm{~A} \text {, nickel } \\
111 \mathrm{~B}, \text { nickel } \\
111 \mathrm{C} \text {, nickel........... }\end{array}$ & $\begin{array}{l}.35 \\
.35 \\
.35\end{array}$ & $\begin{array}{l}.042 \\
.042 \\
.042\end{array}$ & $\begin{array}{l}.02 \\
.03 \\
.25\end{array}$ & $\begin{array}{l}\text { Not malleable. } \\
\text { Do. } \\
\text { Malleable. }\end{array}$ \\
\hline $\begin{array}{l}94 \mathrm{~A}, \text { nickel } \\
94 \mathrm{~B}, \text { nickel } \\
94 \mathrm{C}, \text { nickel }\end{array}$ & $\begin{array}{l}.21 \\
.21 \\
.21\end{array}$ & $\begin{array}{l}.046 \\
.046 \\
.046\end{array}$ & $\begin{array}{r}4 \text { None. } \\
.039 \\
.080\end{array}$ & $\begin{array}{l}\text { Brittle. } \\
\text { Malleable. } \\
\text { Do. }\end{array}$ \\
\hline $\begin{array}{l}87 \mathrm{~A} \text {, nickel } \\
87 \mathrm{~B} \text {, nickel- } \\
87 \mathrm{C} \text {, nickel }\end{array}$ & $\begin{array}{l}.40 \\
.40 \\
.40\end{array}$ & $\begin{array}{l}.104 \\
.104 \\
.104\end{array}$ & $\begin{array}{l}\text { None. } \\
.15 \\
.24\end{array}$ & $\begin{array}{l}\text { Brittle. } \\
\text { Malleable. } \\
\text { Do. }\end{array}$ \\
\hline 123, nickel ... & & .02 & .2 & Do. \\
\hline
\end{tabular}

It appears from the results tabulated in Table 3 that an addition of magnesium equivalent to the sulphur content is all that is required to make nickel malleable.

A melt of nickel (No. 95) containing 1.75 per cent manganese, 0.045 per cent sulphur, and 0.34 per cent carbon was made malleable by the addition of 0.038 per cent magnesium. As a similar melt containing no manganese (No. 94) was made malleable by the addition of 0.039 per cent magnesium, it seems that the manganese content has no effect on the amount of magnesium required to make nickel malleable.

The most plausible explanation for the effect of manganese and of magnesium is that each will take the sulphur from the nickel and by forming manganese or magnesium sulphide eliminate the dangerous nickel sulphide. This was readily demonstrated in several ways.

It is known that manganese has a somewhat greater affinity, and that magnesium has a very much greater affinity, for sulphur than has nickel.

It was demonstrated that both manganese and magnesium react with nickel sulphide $\left(\mathrm{Ni}_{3} \mathrm{~S}_{2}\right)$ at the temperature of molten nickel. A fusion of metallic manganese and nickel sulphide $\left(\mathrm{Ni}_{3} \mathrm{~S}_{2}\right)$ in an alundum crucible produced a metallic button and a slag. This slag decomposed in cold 0.25 per cent (by volume) hydrochloric acid, with evolution of hydrogen sulphide, but was not decomposed by cold or boiling distilled water. A similar fusion of nickel sulphide and magnesium produced a metallic button and a slag. This slag decomposed in cold distilled water, hydrogen sulphide being given off. As nickel sulphide $\left(\mathrm{Ni}_{3} \mathrm{~S}_{2}\right)$ was not attacked under similar conditions, it was evident that both the manganese and the magnesium had reacted with the nickel sulphide. 
To determine if similar reactions occurred in nickel, three ingots were obtained from a melt of nickel containing 0.23 per cent sulphur. The first ingot ( $83 \mathrm{~A}$ ) was obtained from a melt of electrolytic nickel to which 0.23 per cent sulphur was added as $\mathrm{Ni}_{3} \mathrm{~S}_{2}$; the second ingot (83B) was poured from the same melt after the addition of 3 per cent manganese, and the third ingot ( $83 \mathrm{C}$ ) was poured after the addition of 0.5 per cent magnesium. When specimens of these ingots were drilled under 5 per cent (by volume) hydrochloric acid, $83 \mathrm{~A}$ gave off no hydrogen sulphide and $83 \mathrm{~B}$ and $83 \mathrm{C}$ did. When these specimens were drilled under water, $83 \mathrm{~A}$ and $83 \mathrm{~B}$ gave no hydrogen sulphide and $83 \mathrm{C}$ did. These tests were not so satisfactory as might appear, because the speed and sharpness of the drill by affecting the temperature of the drillings had considerable effect on the amount of hydrogen sulphide liberated. However, they confirmed the presence of MnS in the B sample and of MgS in the C sample.

A more satisfactory indication of differences in the sulphur constituents ras obtained by sulphur printing specimens from the three ingots. Two per cent sulphuric acid (by volume) was used, and the specimens were in contact with the photographic printing paper for two minutes. When the specimens were polished in air, a light print was obtained on $83 \mathrm{~A}$ and $83 \mathrm{C}$, while a dark print was obtained on $83 \mathrm{~B}$. When the specimens were prepared by polishing under absolute alcohol, a light print was obtained on $83 \mathrm{~A}$ and darker prints on $83 \mathrm{~B}$ and $83 \mathrm{C}$. These prints are shown as Figure $7, a$.

A similar set of sulphur prints were obtained on specimens from a commercial melt of Monel metal. The melt was No. 4,952, and the chemical analysis of this melt was $\mathrm{C}$, 0.16 per cent; Mn, 1.65 per cent; Fe, 1.82 per cent; Si, 0.07 per cent; and S, 0.029 per cent. Specimen No. 1 was taken from the furnace before any addition, specimen No. 2 was taken from the ladle after the addition of manganese, and specimen No. 3 was taken after the addition of 0.1 per cent magnesium. These specimens were sulphur printed with 2 per cent sulphuric acid, and the time of contact was 10 minutes. These prints are shown as Figure $7, b$.

It is believed that these sulphur prints indicate that sulphur may be present in nickel or Monel metal in any of three forms, depending upon the treatment the metal has received.

The mechanism of the effect of treating sulphur-bearing nickel with manganese and magnesium is also well demonstrated by thermal analysis. Inverse rate heating and cooling curves are shown in Figure 8 . Specimen $83 \mathrm{~A}$ contained 0.23 per cent sulphur but no manganese or magnesium. Specimen 100 contained 2.33 per cent sulphur and 7.96 per cent manganese, and specimen $83 \mathrm{C}$ was cast from the same melt as $83 \mathrm{~A}$ after the addition of 3 per cent manganese and 0.5 per cent magnesium. It will be observed that specimen $83 . \Lambda$, which 


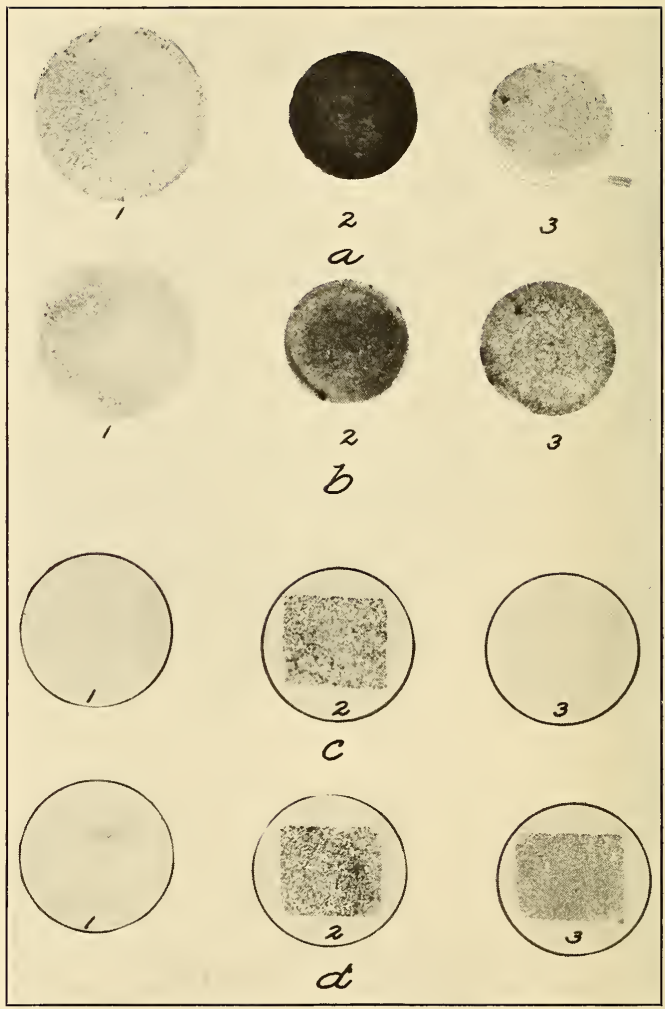

FIG. 7.-Sulphur prints of nieliel and Monel metal melts indicating differences in the sulphur constituents

(a) Nickel specimen 83A, 0.23 per cent sulphur, 83B, and 83C (fig. 3) polished in air and moistened with water, (1) as cast, (2) same treated with 3 per cent manganese, (3) same after further treatment, 0.5 per cent magnesium

(b) Same specimens repolished under alcohol

(c) Monel metal specimen $4953,0.29$ per cent sulphur, polished in air, and kept wet with water, (1) as cast, (2) same treated with 1.65 per cent manganese, (3) same atter further treatment with 0.1 per cent magnesium

(d) Same specimen as $c$ repolished under alcohol 


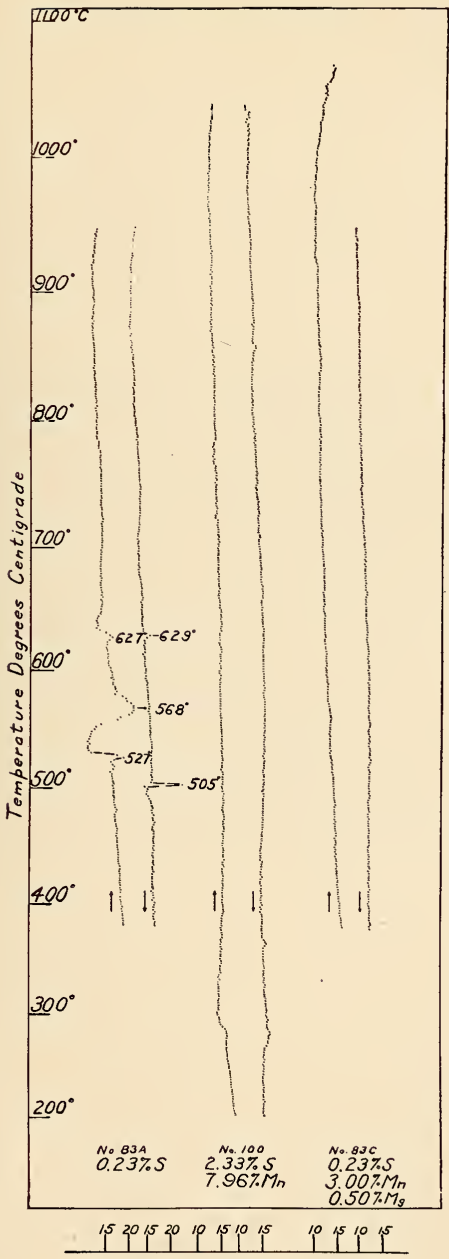

Time in seconds to heat or cool $2^{\circ} \mathrm{C}$

$\approx$

․ㅗㄹ

औิ

ङ

苛过

त)

สี हี

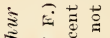

ミ

$\rightarrow=\varnothing$

$\stackrel{\nabla}{*} \dot{\nabla}$

유 핼

ङ

i

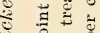

¿ ڤ

-

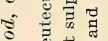

ङ

इ 芯范

$\stackrel{\vec{*}}{\circ}$

- $\mathrm{g}$

ङ

¿ $\cong$

का कo

ఏ क

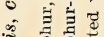

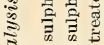

ङ

ङ

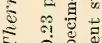

(1)

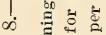

घ) छै कै

E

焉焉

$\exists$ a

我官焉

$\exists$ is

घี

苋记

is 
was untreated, exhibits the nickel sulphide eutectic arrest at $630^{\circ}$ C. $\left(1,166^{\circ} \mathrm{F}\right.$. $)$, as well as an arrest at a lower temperature, $530^{\circ}$ C. $\left(986^{\circ} \mathrm{F}.\right)$. This latter arrest is presumed to be due to a transformation in $\mathrm{Ni}_{3} \mathrm{~S}_{2}$, as thermal analyses of fused $\mathrm{Ni}_{3} \mathrm{~S}_{2}$ gave very sharp and long arrests at that point. ${ }^{10}$

Treatment with manganese, as well as that with manganese followed by magnesium, eliminates the nickel sulphide arrests completely. The $\mathrm{MnS}$ eutectic arrest is above the range of these observations and was demonstrated to occur at $1,325^{\circ} \mathrm{C}$. $\left(2,417^{\circ} \mathrm{F}\right.$.) by thermal analyses of nickel melts carrying sulphur and treated with manganese.

The microstructure of this series so analyzed is typical and is shown in Figure 3. $\mathrm{Ni}_{3} \mathrm{~S}_{2}$ is present in the untreated sample (fig. $3, a), \mathrm{MnS}$ in the second specimen treated only with manganese (fig. $3, b$ ), and $\mathrm{MgS}$ in the specimen treated with magnesium (fig. 3, c).

In nickel containing sulphur in ordinary amounts-about 0.02 per cent-to which manganese has been added the sulphur constituent appears as globules in the grain boundaries and has a bluish gray color. When etched with the nitric-acetic acid solution these inclusions are attacked and stains are formed around them as shown in $74 \mathrm{~B}$ (fig. $4, b$ ) and $\mathrm{X}_{2}$ (fig. 5, b). The inclusions in Monel which has been treated with manganese have the same appearance, but the adjacent Monel metal is not stained on etching. This manganesesulphur constituent is not attacked when the specimen is immersed for fire seconds in 10 per cent KCN, but the copper-sulphur constituent is attacked. These inclusions in Monel are shown in M2 (fig. 6, b). Observations on specimens of nickel containing large amounts of sulphur and manganese have shown that the manganese sulphide forms a eutectic with nickel containing about 3.1 per cent sulphur. This eutectic melts at $1,325^{\circ} \mathrm{C}$. $\left(2,417^{\circ} \mathrm{F}\right.$.), and its appearance is shown in specimen 100 (fig. 9) and in specimen 83B (fig. 3, b).

The reaction between manganese and nickel sulphide in molten nickel does not appear to be quantitative unless one regard the sulphide as having the composition $\mathrm{Mn}_{3} \mathrm{~S}_{2}$. This is shown by examination of some specimens having larger amounts of sulphur and manganese, the results of which are given in Table 4 :

TABLE 4.-Equilibrium conditions for nickel, sulphur, and manganese

\begin{tabular}{|c|c|c|c|c|c|}
\hline Specimen No. & $\mathrm{Mn}$ & $\mathrm{S}$ & $\begin{array}{l}\text { Free } \\
\text { Mn }^{a}\end{array}$ & $\begin{array}{l}\text { Free } \\
\text { Mn }{ }^{b}\end{array}$ & Remarks \\
\hline $\begin{array}{l}117 \\
98 \\
100 \\
116\end{array}$ & $\begin{array}{r}\text { Pet cent } \\
4.97 \\
3.90 \\
7.96 \\
7.56\end{array}$ & $\begin{array}{r}\text { Per cent } \\
2.60 \\
1.44 \\
2.33 \\
2.92\end{array}$ & $\begin{array}{r}\text { Per cent } \\
0.5 \\
1.4 \\
4.0 \\
2.6\end{array}$ & $\begin{array}{r}\text { Per cent } \\
-1.7 \\
.3 \\
2.0 \\
.1\end{array}$ & $\begin{array}{l}\text { Large amount } \mathrm{Ni}_{3} \mathrm{~S}_{2} . \\
\text { Do. } \\
\text { None. } \\
\text { Do. }\end{array}$ \\
\hline
\end{tabular}

a Assuming sulphide of manganese to be Mns.

$b$ Assuming sulphide of manganese to be $\mathrm{Mn}_{3} \mathrm{~S}_{2}$.

${ }^{10}$ See Bornemann, footnote 8 ; and Hayward, footnote 9, p. 165. 
As was found when the sulphur prints were made, the sulphur constituent in nickel and Monel metal which has been treated with magnesium decomposes in the presence of water. When polished in the ordinary manner, by using water with an abrasive, the specimens contained pits distributed through the grains of the metal. These pits were the result of the decomposition of the magnesium-sulphur constituent and are shown in $74 \mathrm{C}$ (fig. $4, c$ ). The magnesium-sulphur constituent was identified by using alcohol in place of water with the abrasive while polishing specimens. It was then found that the magnesium-sulphur constituent is distributed through the grains of nickel or Monel as hexagonal inclusions with a bright blue color. These inclusions are shown in nickel in 83C (fig. 3, c), and

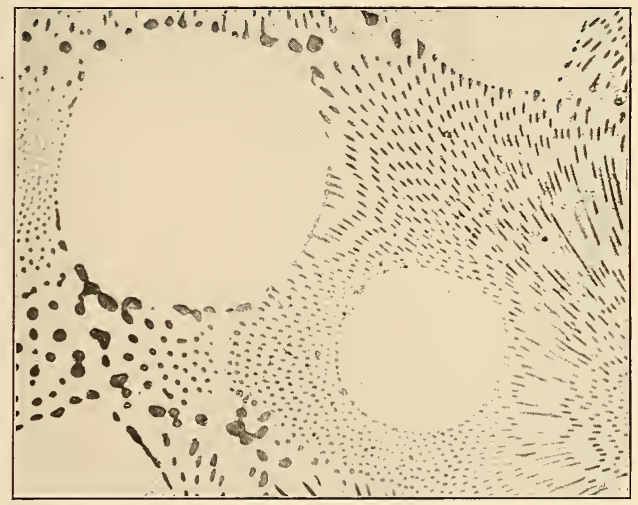

FIg. 9.-Wicrostructure of nickel containing mangancse sulphide eutectic, $\times 500$

Specimen 100 ; etched, 2.53 per cent sulphur and 7.96 per cent manganese (fig.8)

in $\mathrm{X}$ 3 (fig. $5, c$ ). Their appearance in Monel is shown in Mr3 (fig. $6, c)$. These inclusions decompose when the specimens are immersed in water, so it is concluded that they are magnesium sulphide. Their distribution and appearance indicate that the magnesium sulphide is insoluble in nickel and Monel metal, and that it solidifies at a higher temperature than either nickel or Monel metal.

The presence of manganese in either nickel or Monel metal apparently has no effect on the formation or appearance of magnesium sulphide.

An interesting fact is that nickel or Monel metal containing sulphur and made malleable by the addition of manganese and magnesium becomes nonmalleable when melted in an oxidizing atmosphere. Apparently under such conditions the magnesium-sulphur 
constituent breaks down, and the objectionable nickel sulphide constituent is formed. Therefore, it is desirable that additions of magnesium be made shortly before pouring a melt.

Although the rôle of magnesium with respect to sulphur has here been emphasized as constituting the essential mechanism of the restoration of malleability, the authors realize that it is not necessarily the only rôle magnesium plays in the treatment of furnace nickel. Magnesium undoubtedly does so react where used commercially as a finishing agent for nickel or Monel metal. That it does serve to reduce the gas content of these metals is proved by analyses recently made at the Bureau of Standards by L. Jordan, chemist, of samples submitted by The International Nickel Co. Three samples of a regular Monel metal heat were taken (1) before any treatment, (2) after treatment with the usual amount of ferromanganese, and (3) after additional treatment with the usual amount of magnesium. The total oxygen and hydrogen contents of these samples are given below :

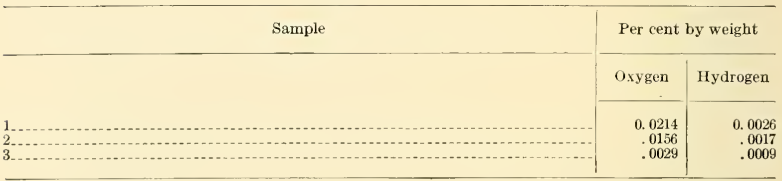

It is quite evident that the magnesium removed oxygen which was not removed by the manganese addition.

Inasmuch as the magnesium added to molten nickel or Monel metal reacts with both oxides and with sulphides, in practice the amount added must divide itself between these two reactions and probably with greater affinity for the oxide reactions. Hence, if the metal before treatment with magnesium is not already sufficiently deoxidized by other means, all of the magnesium may be used up in completing the deoxidation proper. In this case none or insufficient magnesium will be left for the sulphide conversion, and the metal produced will not be malleable. Cases of irregularity in the results produced by adding magnesium in commercial practice may probably be traced to this cause.

\section{EFFECT OF EXCESS OF MAGNESIUM}

As magnesium is usually added in excess of that required for the sulphur present, a few melts were made with the object of determining what effect an excess of magnesium has on the malleability of nickel and Monel metal. As much as 0.5 per cent was added to nickel with- 
out appreciably affecting its malleability. The maximum amount of magnesium found by chemical analysis was 0.33 per cent. An excess of magnesium in Monel metal is more harmful, specimens containing more than 0.2 per cent magnesium are not malleable, and when the magnesium content is in excess of 0.4 per cent Monel metal is brittle at forging temperatures $\left(1,050\right.$ to $1,100^{\circ} \mathrm{C}$.) .

The magnesium-nickel constituent appears in nickel as irregularly shaped inclusions at the grain boundaries. Before etching these inclusions are faintly evident, but a light etching with the nitric-acetic acid solution reveals them as a gray inclusion which may be eutectic. The appearance of the magnesium sulphide and magnesium-nickel constituents are shown in Figure 10, $a$ and $b$.

Guertler, in his Metallographie, 1912, page 418, states that a compound $\left(\mathrm{Ni}_{2} \mathrm{Mg}\right)$ is formed in nickel rich alloys of magnesium. This compound forms a eutectic with nickel at 11 per cent magnesium and the melting point of this eutectic is given as $1,082^{\circ} \mathrm{C} .\left(1,980^{\circ} \mathrm{F}\right.$.). He indicates that about 2 per cent magnesium is soluble at the eutectic temperature. Thermal analyses of some of the specimens indicate that the eutectic temperature is $1,095^{\circ} \mathrm{C}$. $\left(2,003^{\circ} \mathrm{F}\right.$. $)$. As the magnesium-nickel constituent is evident in specimens containing 0.1 per cent magnesium as cast and after heating to $1,100^{\circ} \mathrm{C}$. $\left(2,012^{\circ} \mathrm{F}\right.$.), its solubility in solid nickel must be less than 0.1 per cent.

The magnesium-nickel or copper constituent in Monel metal has not been identified. When no sulphur is present with increasing magnesium content, from 0.1 to 0.6 per cent, there are increasing numbers of small brownish inclusions throughout the grains of Monel. From their distribution one might expect their effect on the malleability to be less than the effect of $\mathrm{Ni}_{2} \mathrm{Mg}$ in nickel, but, as was stated above, such is not the case.

\section{SUMMARY AND CONCLUSIONS}

The results of this investigation may be summarized as follows: First, in order to determine whether pure nickel is naturally nonmalleable, or whether it is rendered so by the presence of impurities, a series of small laboratory melts was made of pure electrolytic nickel, to which were added in some cases known amounts of different impurities. The ingots of these melts were then hammered hot and cold and otherwise tested for malleability and ductility. From these tests certain definite conclusions were reached.

1. Of those elements or compounds naturally occurring in commercial cast nickel, viz, carbon, silicon, iron, copper, arsenic cobalt, manganese, oxygen, and sulphur, the latter alone is responsible for its nonmalleability when untreated. The presence of gases in nickel. such as carbon monoxide, carbon dioxide, hydrogen, and nitrogen. 
has likewise no effect on its malleability, except in so far as the presence of blowholes impairs it.

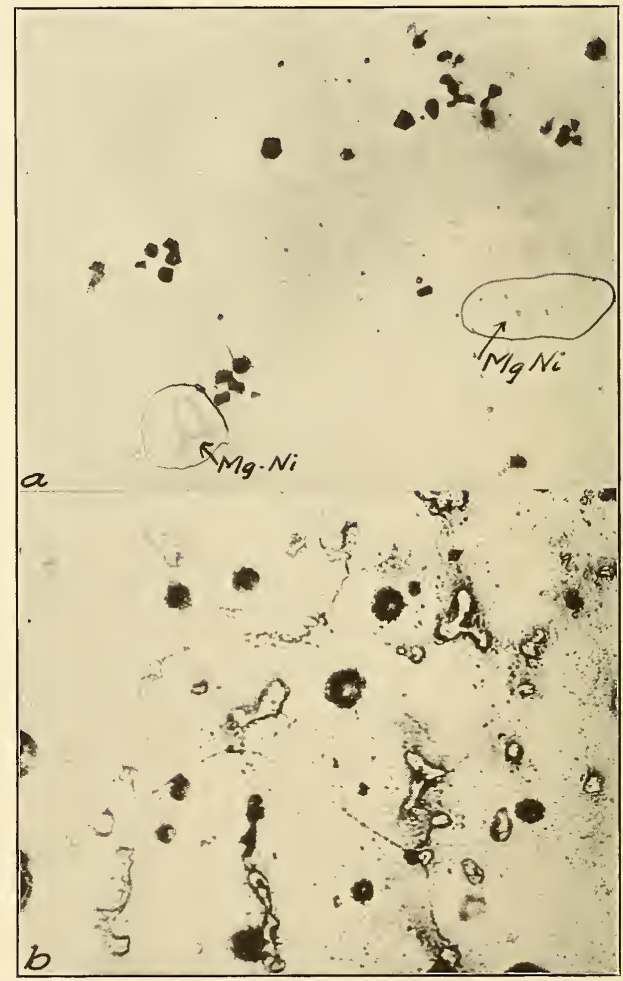

Fig. 10.-Microstructure of nickel trcated with magnesium, $\times 500$

(a) Specimen $83 \mathrm{C}$, unetched, 0.23 per cent sulphur treated with 3 per cent manganese and 0.5 per cent magnesinm (fig. 8), unetched. Note the magnesium sulphide inclusions and the $\mathrm{Mg}-\mathrm{Ni}$ compound

(b) Same after etching with the nitric acid-acetic acid reagent. The magnesium sulphide has been pitted and the magnesium-nickel compound is evident at the grain boundaries

2. Commercial electrolytic nickel containing less than 0.005 per cent sulphur is essentially malleable, both hot and cold, before and after remelting and without any manganese or magnesium treatment. It can absorb the usual amounts of such impurities as carbon, 
silicon, manganese, iron, copper, cobalt, oxygen, and arsenic and remain quite malleable. ${ }^{11}$

3. As little as 0.01 per cent of sulphur introduced into remelted electrolytic nickel renders it almost completely nonmalleable; in order that cast nickel may be malleable without treatment the sulphur content must be (probably substantially) below 0.005 per cent.

4. This profound effect of such a small amount of sulphur is due to the formation of a film of nickel sulphide $\left(\mathrm{Ni}_{3} \mathrm{~S}_{2}\right)$ which surrounds each metallic grain of nickel and lowers effectively the intercrystalline cohesion of the mass of grains even at low temperature. This sulphide (eutectic) melts at $630^{\circ} \mathrm{C}$., and at higher temperatures there is in consequence practically no cohesion between the nickel grains.

5 . The addition of small amounts of manganese $(0.50$ to 1.0 per cent) to nickel containing 0.01 per cent sulphur and over slightly improres its malleability. The addition of still smaller amounts of magnesium ( 0.05 to 0.10 per cent) completely restores its malleability.

6. The facts noted ( 1 to 5) apply equally well to Monel metal and probably to other alloys of high nickel content.

Having thus determined the origin of the nonmalleability of nickel it remained to study the mechanism of the curative action of manganese and magnesium, chiefly by investigating the chemical reactions resulting from the addition of manganese and megnesium to nickel containing sulphur. The conclusions of these studies were:

7. Manganese reacts with nickel sulphide $\left(\mathrm{Ni}_{3} \mathrm{~S}_{2}\right)$ to form manganese sulphide (probably $\mathrm{MnS}$ ) and nickel; this reaction is probably not quantitative, but reaches an equilibrium determined by the concentration of the excess manganese in solution in the nickel. The manganese sulphide forms an eutectic with nickel melting at $1,325^{\circ} \mathrm{C}$., and its distribution in the solid nickel, although along the grain boundaries, takes the form of small globules, and not films as does nickel sulphide. Its deleterious effect on the grain cohesion is not so great as that of the latter. In consequence, the addition of manganese improves the malleability of nickel but does not restore it completely.

8. Magnesium has a higher "affinity" for sulphur than either nickel or manganese and reacts apparently almost quantitatively with either manganese or nickel sulphide to form magnesium sulphide. The latter is insoluble in molten nickel and, indeed, is solid at these temperatures (about $1,460^{\circ}$ C.), forming small crystalline

\footnotetext{
${ }^{11}$ After the completion of this work B. Bogitch (Compt, rend, 178, p. 855; 1924) states that 0.005 per cent sulphur makes nickel cubes or rondelles nonmalleable, whereas they are malleable when the sulphur content is lowcr. These statements confirm very well the conclusions of this investigation.
} 
particles which are entrapped during the solidification of the nickel and dispersed throughout the grains. They are not concentrated at the grain boundaries and exert practically no effect in consequence of their uniform mode of distribution on the cohesion or malleability of the nickel. Magnesium additions, therefore, restore the ductility of cast nickel containing sulphur by changing the form of the sulphur from $\mathrm{Ni}_{3} \mathrm{~S}_{2}$ to $\mathrm{MgS}$ and its distribution from that of intererystalline films of $\mathrm{Ni}_{3} \mathrm{~S}_{2}$ (of low melting point) to that of uniformly dispersed equiaxed particles of MgS (of high melting point). In connection with this investigation a study was made of the equilibrium between nickel and nickel oxide.

9. Although the principal function of magnesium, and of manganese to a less extent, in rendering cast nickel malleable is thus demonstrated to be its effect in changing the form of the sulphur present, it should not be thought that this is the only rôle it plays. Magnesium undoubtedly reacts, as Fleitmann originally claimed, with oxides, and particularly with carbon monoxide present, and this also serves to "degasify" the molten metal as well. Irregularities in the effects produced by added magnesium may, indeed, be traced very probably to a varying distribution of the amount between these two functions.

10. Nickel oxide ( $\mathrm{NiO})$ and nickel appear to form a simple eutectic series, the eutectic containing 0.24 per cent oxygen or 1.1 per cent $\mathrm{NiO}$ melting at $1,438^{\circ} \mathrm{C}$. The solubility of nickel oxide in solid solution in nickel appears to be slight.

This work was carried on by R. G. Waltenberg as research associate of The International Nickel Co. at the Bureau of Standards, and the authors desire to express their deep appreciation of the privilege of this association with the bureau, and of the many courtesies and aid of its director, Dr. George K. Burgess. They are indebted as well to H. A. Bright and J. A. Scherrer, of the bureau, for many chemical analyses, and to E. J. Ruh, research assistant, for general assistance; also to Miss I. J. Wymore, assistant chemist, for most of the thermal analyses included in this paper. To A. J. Wadhams, manager of development and research department of the International Nickel Co., a special measure of thanks is due for the generous and sympathetic support he has accorded this work at all times.

Washington, September 19, 1924. 